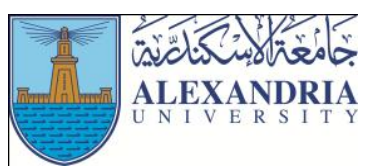

\author{
Journal of Applied Sports Science \\ April 2017, Volume 7, No. 1 \\ www.jass.alexu.edu.eg
}

\title{
Health Services Provided to Hail University Students According to Quality and Accreditation Standards
}

\author{
Sameh Fawzi Abdel Fattah ${ }^{1}$ \\ ${ }^{1}$ Assistant Professor, Sport Health Sciences Department, Faculty of Physical Education, Al-Azhar University, Egypt
}

\begin{abstract}
The research aimed at identify health services provided to Hail University students according to quality and accreditation standards. Fifty university leaders and (550) students selected from the elven faculties seeking accreditation in Hail university (50 students/college), 20 incomplete questionnaires excluded. Questionnaire for measuring health services quality in Hail University (prepared by researcher) used as data collecting tool. The most important results indicated lack of quality standards in health services provided to university students
\end{abstract}

\section{Introduction}

$\mathrm{H}$ ealth aspects are of educational institutions evaluation aspects, it aims at improving of students' health by providing necessary preventive, curative, and rehabilitative care at a high efficiency level. This to be done considering achieving objectives in terms of accessibility and comprehensiveness. (AlShamaa, 2014, p. 53).

Health services are of essential elements of any community development (Alhayati, 2008, p .290)

Student's preparation and his satisfaction with what presented to him and its effect on his skills and their association with labour market is within criteria of accreditation. (Al-Aklabi \& Al-Refaei, 2012, p .242)

Accordingly, quality provides educational institution with clear vision and mission of its role nature, and sets specific goals to achieve, sets expected levels of performance, directs staff efforts; and provides an objective reference for self-assessment. (Ramadan, 2012, p .109).

The role of educational institutions cannot be limited to curricula alone, or through combination of curricula and environment. However, the services available are the third partner in health and learning promotion. (Amin \& Abdullah, 2009, p .2-3).

When talking about health services at university, we keep in mind the comprehensive concept of health, which includes four aspects (psychological, physical, social and mental), which must be taken into account when providing health services to university students (Abdulfatah \& Abu Dalbouh, 2014, p .10).

Several scientific studies have indicated that students' health level is correlated with scholastic superiority, psychological balance, and identification of appropriate specialization in future, and then work and production (Ismail, 2006, p.2).

Universities are of most important educational institutions in the society. It contributes to individual preparation in all life aspects by providing healthy environment suitable for all services provided to the student. Health services (development - preventiontreatment) is of the conditions required in university environment. (Al-Shamaa, 2014, p.30).

Universities care about its students' health and provides them with health services through medical clinics and university hospitals. It also promotes dissemination of health culture through holding conferences and seminars that deal with issues related to various health aspects. (Amin \& Abdullah, 2009, p . 68).

There is no doubt that health services are a prerequisite for any institution to obtain a certificate of quality and accreditation. However, the actual reality of these services has not received its attention and study, as there are no scientific studies show the reality of these services in universities and its quality and compare them with what should be. 
Researcher observed that there is lack of health care and health services provided to students. There is no properly equipped sports playgrounds to practice various sports activities. There is no well-supervised restaurants offer fresh meals to students. Although these colleges are prepared to apply for quality and accreditation and by National Quality and Accreditation Authority. Health issues awareness was absent.

Through analysis of many researches and studies specialized in health quality services in universities, researcher found that sport library lacks this research aspect, therefore, researcher thought to conduct this research to identify (health services provided to students of Hail University according to quality and accreditation standards

This research is important, as it will work to identify reality of health services at Hail. University, improving health services provided to Hail university students by making proposals to officials.

The research aims at identify health services provided to Hail University students according to quality and accreditation standards, the research tries to answer the following queries: What are the health services provided to Hail University students?, and Are quality and accreditation standards available in health services provided to Hail University students?

\section{Research Terms}

\section{1- Health services}

A set of preventive services that, if applied, prevent individuals from having diseases, including proper nutrition, complete periodic medical examination, prevention of infectious diseases, first aid, body care and maintenance, and provision of prosthetic devices and treatments services for normal and disabled students (Swedan, 1999, p. 10).

\section{2- Health services for university students:}

The services provided by the University for students in the three health pillars (health development, prevention, treatment), which include health education, sports services, proper nutrition, psychological counselling, healthy university environment, and medical care. (Procedural definition)

\section{3- National standards for educational quality and accreditation}

A set of local standards in line with international standards and in a manner that suits the Arab environment to meet minimum requirements. (Alhayati, 2008, p .29; Abdulazim \& Abdulrazeq, 2002, p .98 )

\section{4- Health services quality}

The commitment degree to contemporary recognized standards for good practice, expected results for a specific service, diagnostic procedure or medical problem, and to achieve desired health outcomes in accordance with professional principles.( Al-Ahamadi, 2000, p .409; Qassem, 2008, p.13). Health care quality concept includes several elements, the most important of which are access to health care, health care sustainability, health care effectiveness and efficiency, beneficiaries' expectations and satisfaction with health care, health-care facilities status, and health care environment Safety and safety. (Al-Emary, 2011, p .47)

\section{Method}

\section{Subjects}

Fifty university leaders and (550) students selected from the elven faculties seeking accreditation in Hail university (50 students/college) (appendix 1), 20 incomplete questionnaires excluded.

\section{Measures}

Questionnaire for measuring health services quality in Hail University (prepared by researcher)

\section{Procedures}

\section{Questionnaire design}

The researcher prepared a questionnaire included several aspects and was presented to experts and specialists (appendix 2) to express their opinion on appropriate aspects of the questionnaire. The researcher accepted aspects that got $80 \%$ approval at least to be use to design the initial form of the questionnaire (appendix 3 ), aspects arrived are: Health education for students, Sports services, Health Nutrition Services, Psychological Counselling Services, Healthy university environment, Medical services and Health services quality. The initial questionnaire form presented to experts included (112) phrases distributed among aspects.. The researcher made all experts recommendations. Thus, the final questionnaire form (appendix 4) included 89 phrases distributed among aspects. Experts selected three responses scale (yes, To some extent, and No) with scores $(3,2,1)$ respectively. 


\section{Pilot study}

Conducted on (50) individuals from research community and not in main study sample in the period from $15 / 10 / 2015$ to $15 / 1 / 2015$ and aimed at identifying phrases' clarity, relevance and understanding by sample, and ensure questionnaire validity and reliability, results of pilot study indicated Appropriate measurement of research nature, and Questionnaire instructions clarity.

\section{Questionnaire validity and reliability}

Content validity ensured by presenting the questionnaire to experts, who agreed questionnaire phrases with 80 $100 \%$ approval percentage. Correlation between each phrase and its aspect calculated and ranged between 0.568 and 0.689 i.e. values significant at 0.01 level, the matter which confirm questionnaire validity. Questionnaire reliability checked using alpha Cronbach coefficient that ranged between $(0.746-0.889)$ which is high values, indicating questionnaire reliability.

\section{Main study implementation}

Questionnaire administered on research sample in the period from $1 / 2 / 2016$ to $1 / 4 / 2016$. .

\section{Statistical process:}

SPSS statistics software program used to analyse research data utilizing the following statistics: frequency, percentage, mean, standard deviation, Pearson correlation coefficient, and independent $\mathrm{T}$ test. 0.05 significance level adopted throughout the research.

\section{Results and Discussion}

The researcher will present, discuss and interpret the results reached, limited by research and methodology used to answer research queries, guided by scientific references and previous studies as well as his vision in interpreting these results.

Table (1)

First aspect responses (Health education for students) $(\mathbf{n = 5 8 0})$

\begin{tabular}{|c|c|c|c|c|c|c|c|c|c|}
\hline \multirow[b]{2}{*}{ S.No. } & \multirow[b]{2}{*}{ Phrase } & \multirow[b]{2}{*}{ Group } & \multicolumn{4}{|c|}{ Responses } & \multirow{2}{*}{$\begin{array}{c}\text { Relative } \\
\text { weight }\end{array}$} & \multirow{2}{*}{$\begin{array}{c}\text { Incidence } \\
\text { degree }\end{array}$} & \multirow[b]{2}{*}{ Rank } \\
\hline & & & & No & $\begin{array}{c}\text { To some } \\
\text { extent }\end{array}$ & Yes & & & \\
\hline \multirow{4}{*}{1} & \multirow{4}{*}{$\begin{array}{c}\text { Seminars held for students in health } \\
\text { awareness }\end{array}$} & \multirow{2}{*}{ Students } & Freq. & 177 & 349 & 4 & \multirow{4}{*}{1.6638} & \multirow{4}{*}{ Week } & \multirow{4}{*}{3} \\
\hline & & & $\%$ & $33.4 \%$ & $65.8 \%$ & $0.8 \%$ & & & \\
\hline & & \multirow{2}{*}{ Staff } & Freq. & 22 & 28 & 0 & & & \\
\hline & & & $\%$ & $44.0 \%$ & $56.0 \%$ & $0.0 \%$ & & & \\
\hline \multirow{4}{*}{2} & \multirow{4}{*}{$\begin{array}{l}\text { Distribution of leaflets about } \\
\text { methods of disease prevention }\end{array}$} & \multirow{2}{*}{ Students } & Freq. & 519 & 6 & 5 & \multirow{4}{*}{1.0672} & \multirow{4}{*}{ Week } & \multirow{4}{*}{15} \\
\hline & & & $\%$ & $97.9 \%$ & $1.1 \%$ & $0.9 \%$ & & & \\
\hline & & \multirow{2}{*}{ Staff } & Freq. & 50 & 0 & 0 & & & \\
\hline & & & $\%$ & $100.0 \%$ & $0.0 \%$ & $0.0 \%$ & & & \\
\hline \multirow{4}{*}{3} & \multirow{4}{*}{$\begin{array}{l}\text { Students participate in community } \\
\text { health issues through student } \\
\text { activities }\end{array}$} & \multirow{2}{*}{ Students } & Freq. & 519 & 5 & 6 & \multirow{4}{*}{1.0293} & \multirow{4}{*}{ Week } & \multirow{4}{*}{14} \\
\hline & & & $\%$ & $97.9 \%$ & $0.9 \%$ & $1.1 \%$ & & & \\
\hline & & \multirow{2}{*}{ Staff } & Freq. & 43 & 5 & 2 & & & \\
\hline & & & $\%$ & $86.0 \%$ & $10.0 \%$ & $4.0 \%$ & & & \\
\hline \multirow{4}{*}{4} & \multirow{4}{*}{$\begin{array}{l}\text { Posters placed in fixed places } \\
\text { include some health issues }\end{array}$} & \multirow{2}{*}{ Students } & Freq. & 511 & 6 & 13 & \multirow{4}{*}{1.0672} & & \\
\hline & & & $\%$ & $96.4 \%$ & $1.1 \%$ & $2.5 \%$ & & W & 0 \\
\hline & & & Freq. & 43 & 7 & 0 & & week & 8 \\
\hline & & & $\%$ & $86.0 \%$ & $14.0 \%$ & $0.0 \%$ & & & \\
\hline & & & Freq. & 515 & 8 & 7 & & & \\
\hline 5 & Students made aware of obesity & Students & $\%$ & $97.2 \%$ & $1.5 \%$ & $1.3 \%$ & 1 & T & 13 \\
\hline & risks & $\sigma_{0}$ & Freq. & 43 & 7 & 0 & 1.00 & & \\
\hline & & Staft & $\%$ & $86.0 \%$ & $14.0 \%$ & $0.0 \%$ & & & \\
\hline 6 & Students sensitized to diseases & Student & Freq. & 520 & 6 & 4 & 1060 & W & 10 \\
\hline & caused by malnutrition and lack of & & $\%$ & $98.1 \%$ & $1.1 \%$ & $0.8 \%$ & 1.002 & week & \\
\hline
\end{tabular}




\begin{tabular}{|c|c|c|c|c|c|c|c|c|c|}
\hline & mobility & Stoff & Freq. & 32 & 14 & 4 & & & \\
\hline & & Stait & $\%$ & $64.0 \%$ & $28.0 \%$ & $8.0 \%$ & & & \\
\hline \multirow{4}{*}{7} & \multirow{4}{*}{$\begin{array}{l}\text { Students made aware of smoking } \\
\text { dangers }\end{array}$} & \multirow{2}{*}{ Students } & Freq. & 66 & 298 & 166 & \multirow{4}{*}{2.131} & \multirow{4}{*}{ Medium } & \multirow{4}{*}{1} \\
\hline & & & $\%$ & $12.5 \%$ & $56.2 \%$ & $31.3 \%$ & & & \\
\hline & & \multirow{2}{*}{ Staff } & Freq. & 30 & 14 & 6 & & & \\
\hline & & & $\%$ & $60.0 \%$ & $28.0 \%$ & $12.0 \%$ & & & \\
\hline \multirow{4}{*}{8} & \multirow{4}{*}{$\begin{array}{l}\text { College and University web site } \\
\text { used for health awareness }\end{array}$} & \multirow{2}{*}{ Students } & Freq. & 515 & 8 & 7 & \multirow{4}{*}{1.0517} & \multirow{4}{*}{ Week } & \multirow{4}{*}{12} \\
\hline & & & $\%$ & $97.2 \%$ & $1.5 \%$ & $1.3 \%$ & & & \\
\hline & & \multirow{2}{*}{ Staff } & Freq. & 46 & 0 & 4 & & & \\
\hline & & & $\%$ & $92.0 \%$ & $0.0 \%$ & $8.0 \%$ & & & \\
\hline \multirow{4}{*}{9} & \multirow{4}{*}{$\begin{array}{l}\text { College has a compulsory syllabus } \\
\text { includes basic health issues }\end{array}$} & \multirow{2}{*}{ Students } & Freq. & 110 & 361 & 59 & \multirow{4}{*}{1.8397} & \multirow{4}{*}{ week } & \multirow{4}{*}{2} \\
\hline & & & $\%$ & $20.8 \%$ & $68.1 \%$ & $11.1 \%$ & & & \\
\hline & & \multirow{2}{*}{ Staff } & Freq. & 42 & 8 & 0 & & & \\
\hline & & & $\%$ & $84.0 \%$ & $16.0 \%$ & $0.0 \%$ & & & \\
\hline \multirow{4}{*}{10} & \multirow{4}{*}{$\begin{array}{l}\text { Full-screen displays health } \\
\text { awareness }\end{array}$} & Students & Freq. & 513 & 9 & 8 & & & \\
\hline & & Students & $\%$ & $96.8 \%$ & $1.7 \%$ & $1.5 \%$ & 1.081 & Wogl & 7 \\
\hline & & Stoff & Freq. & 37 & 4 & 9 & & ween & $r$ \\
\hline & & Stant & $\%$ & $74.0 \%$ & $8.0 \%$ & $18.0 \%$ & & & \\
\hline & & Students & Freq. & 513 & 9 & 8 & & & \\
\hline 11 & Teacher is keen to link health to & & $\%$ & $96.8 \%$ & $1.7 \%$ & $1.5 \%$ & 1.0828 & Weok & 6 \\
\hline & syllabuses topics & Staff & Freq. & 35 & 7 & 8 & & 烈 & \\
\hline & & & $\%$ & $70.0 \%$ & $14.0 \%$ & $16.0 \%$ & & & \\
\hline & & Students & Freq. & 513 & 11 & 6 & & & \\
\hline 12 & Teacher is keen to direct students to & & $\%$ & $96.8 \%$ & $2.1 \%$ & $1.1 \%$ & 1.0845 & Week & 5 \\
\hline 12 & health-related websites & Ctoff & Freq. & 30 & 14 & 6 & & ween & J \\
\hline & & Stait & $\%$ & $60.0 \%$ & $28.0 \%$ & $12.0 \%$ & & & \\
\hline & & Students & Freq. & 519 & 5 & 6 & & & \\
\hline 12 & The faculty has a health supervisor & & $\%$ & $97.9 \%$ & $0.9 \%$ & $1.1 \%$ & 1.0655 & Wolk & 0 \\
\hline & who works to educate students & Staff & Freq. & 35 & 9 & 6 & & & \\
\hline & & Stant & $\%$ & $70.0 \%$ & $18.0 \%$ & $12.0 \%$ & & & \\
\hline & Colleoe oroanizes comnetitions for & Studente 10 & Freq. & 521 & 4 & 5 & & & \\
\hline 14 & the development of healthy & & $\%$ & $98.3 \%$ & $0.8 \%$ & $0.9 \%$ & 1.0552 & Week & 11 \\
\hline & behaviour among students & Staff & Freq. & 37 & 8 & 5 & & & \\
\hline & & & $\%$ & $74.0 \%$ & $16.0 \%$ & $10.0 \%$ & & & \\
\hline & Distributing leaflets about & Ctol o & Freq. & 293 & 232 & 5 & & & \\
\hline 15 & appropriate food quality and & & $\%$ & $55.3 \%$ & $43.8 \%$ & $0.9 \%$ & 1.0069 & Week & 16 \\
\hline & quantity & Steff & Freq. & 30 & 20 & 0 & & & \\
\hline & & Dtant & $\%$ & $60.0 \%$ & $40.0 \%$ & $0.0 \%$ & & & \\
\hline & & Studente & Freq. & 100 & 422 & 8 & & & \\
\hline 16 & Students provided with first aid & & $\%$ & $18.86 \%$ & $79.62 \%$ & $1.5 \%$ & 1.4517 & Week & 4 \\
\hline & principles & Staff & Freq. & 11 & 35 & 4 & & & \\
\hline & & Stanl & $\%$ & $22.0 \%$ & $70.0 \%$ & $8.0 \%$ & & & \\
\hline
\end{tabular}

Table (1) indicated sample responses according to 1. Students made aware of smoking danger with relative relative weight and incidence degree as following order: weight (2.131) and medium incidence degree. 
This indicates the relative interest in smoking issue because of its spread in secondary and university levels. This concern manifested in several aspects, such as some awareness posters, which prohibit smoking in the campus, and spread awareness of smoking dangers.

The researcher believe in the need to take care of this issue through increasing awareness in intermediate and secondary schools, as well as inclusion of smoking penalty in student guide, which is distributed to students in the preparatory year. As well as the need to use display screens inside colleges to raise awareness of such health issues.

2. College has a compulsory syllabus includes basic health issues with a relative weight (1.8397) and weak incidence degree.

This syllabus available in some faculties as per speciality, and not available in humanities faculties like Faculties of Education and Arts.

The researcher believes in necessity of a mandatory curriculum includes basic health issues related to public health and methods of disease prevention.
The preparatory year introduced health and fitness course in 2012, but it is not compulsory for students in health track, and it needs to be adapted to modern health developments.

3. Hence, this aspect do not get the required attention despite of its importance in shaping students awareness and then modify their health behaviours associated with health habits, such as obesity, nutrition, smoking and awareness of community health issues.

This is what (Ibrahim, 2010) study results revealed that health education helps students to adopt healthy practices among sports activities practitioners and nonpractitioners where they have better health food knowledge and behaviour.

This also consistent with (Amin, 2015) study results, which indicated the need to disseminate food and health culture to students in many ways, and that health education services for students is very important.

The researcher believe that there is a need to pay attention to health education for students.

Table (2)

Second aspect responses (Sport services) $(n=580)$

\begin{tabular}{|c|c|c|c|c|c|c|c|c|c|}
\hline \multirow[b]{2}{*}{ S.No. } & \multirow[b]{2}{*}{ Phrase } & \multirow[b]{2}{*}{ Group } & \multicolumn{4}{|c|}{ Responses } & \multirow{2}{*}{$\begin{array}{c}\text { Relative } \\
\text { weight }\end{array}$} & \multirow{2}{*}{$\begin{array}{c}\text { Incidence } \\
\text { degree }\end{array}$} & \multirow[b]{2}{*}{ Rank } \\
\hline & & & & No & $\begin{array}{l}\text { To some } \\
\text { extent }\end{array}$ & Yes & & & \\
\hline \multirow{4}{*}{1} & \multirow{4}{*}{$\begin{array}{l}\text { University provides } \\
\text { suitable places for } \\
\text { physical activities }\end{array}$} & \multirow{2}{*}{ Students } & Freq. & 29 & 488 & 13 & \multirow{4}{*}{1.9724} & \multirow{4}{*}{ Medium } & \multirow{4}{*}{3} \\
\hline & & & $\%$ & $5.5 \%$ & $92.1 \%$ & $2.5 \%$ & & & \\
\hline & & \multirow{2}{*}{ Staff } & Freq. & 0 & 50 & 0 & & & \\
\hline & & & $\%$ & $0.0 \%$ & $100.0 \%$ & $0.0 \%$ & & & \\
\hline \multirow{4}{*}{2} & \multirow{4}{*}{$\begin{array}{c}\text { The university has a } \\
\text { sports stadium }\end{array}$} & \multirow{2}{*}{ Students } & Freq. & 521 & 5 & 4 & \multirow{4}{*}{1.1724} & \multirow{4}{*}{ Weak } & \multirow{4}{*}{5} \\
\hline & & & $\%$ & $98.3 \%$ & $0.9 \%$ & $0.8 \%$ & & & \\
\hline & & \multirow{2}{*}{ Staff } & Freq. & 37 & 5 & 8 & & & \\
\hline & & & $\%$ & $74.0 \%$ & $10.0 \%$ & $16.0 \%$ & & & \\
\hline \multirow{4}{*}{3} & \multirow{4}{*}{$\begin{array}{c}\text { The College has a } \\
\text { supervisor for sports } \\
\text { activities }\end{array}$} & \multirow{2}{*}{ Students } & Freq. & 82 & 443 & 5 & \multirow{4}{*}{1.8759} & \multirow{4}{*}{ Medium } & \multirow{4}{*}{4} \\
\hline & & & $\%$ & $15.5 \%$ & $83.6 \%$ & $0.9 \%$ & & & \\
\hline & & \multirow{2}{*}{ Staff } & Freq. & 0 & 45 & 5 & & & \\
\hline & & & $\%$ & $0.0 \%$ & $90.0 \%$ & $10.0 \%$ & & & \\
\hline \multirow{4}{*}{4} & \multirow{4}{*}{$\begin{array}{l}\text { College students } \\
\text { participate in sports } \\
\text { teams at the university }\end{array}$} & \multirow{2}{*}{ Students } & Freq. & 5 & 5 & 520 & \multirow{4}{*}{2.9741} & \multirow{4}{*}{ Large } & \multirow{4}{*}{2} \\
\hline & & & $\%$ & $0.9 \%$ & $0.9 \%$ & $98.1 \%$ & & & \\
\hline & & Staff & Freq. & 0 & 0 & 50 & & & \\
\hline & & & $\%$ & $0.0 \%$ & $0.0 \%$ & $100.0 \%$ & & & \\
\hline & The College is keen to & Students & Freq. & 2 & 4 & 524 & & & \\
\hline 5 & form sports teams in & & $\%$ & $0.4 \%$ & $0.8 \%$ & $98.9 \%$ & 2.5002 & Large & 1 \\
\hline & different & Staff & Freq. & 0 & 0 & 50 & & & \\
\hline
\end{tabular}




\begin{tabular}{|c|c|c|c|c|c|c|c|c|c|}
\hline & & & $\%$ & $0.0 \%$ & $0.0 \%$ & $100.0 \%$ & & & \\
\hline \multirow{4}{*}{6} & \multirow{4}{*}{$\begin{array}{c}\text { The college motivates } \\
\text { students who excel in } \\
\text { sport }\end{array}$} & \multirow{2}{*}{ Students } & Freq. & 514 & 12 & 4 & \multirow{4}{*}{1.0483} & \multirow{4}{*}{ Weak } & \multirow{4}{*}{8} \\
\hline & & & $\%$ & $97.0 \%$ & $2.3 \%$ & $0.8 \%$ & & & \\
\hline & & \multirow{2}{*}{ Staff } & Freq. & 46 & 0 & 4 & & & \\
\hline & & & $\%$ & $92.0 \%$ & $0.0 \%$ & $8.0 \%$ & & & \\
\hline \multirow{4}{*}{7} & \multirow{4}{*}{$\begin{array}{l}\text { There is an equipped } \\
\text { gym at college }\end{array}$} & \multirow{2}{*}{ Students } & Freq. & 520 & 5 & 5 & \multirow{4}{*}{1.0259} & \multirow{4}{*}{ Weak } & \multirow{4}{*}{9} \\
\hline & & & $\%$ & $98.1 \%$ & $0.9 \%$ & $0.9 \%$ & & & \\
\hline & & \multirow{2}{*}{ Staff } & Freq. & 50 & 0 & 0 & & & \\
\hline & & & $\%$ & $100.0 \%$ & $0.0 \%$ & $0.0 \%$ & & & \\
\hline \multirow{4}{*}{8} & \multirow{4}{*}{$\begin{array}{l}\text { Teachers instruct their } \\
\text { students to practice } \\
\text { sports during rest times } \\
\text { between lectures }\end{array}$} & \multirow{2}{*}{ Students } & Freq. & 510 & 15 & 5 & \multirow{4}{*}{1.1034} & \multirow{4}{*}{ Weak } & \multirow{4}{*}{7} \\
\hline & & & $\%$ & $96.2 \%$ & $2.8 \%$ & $0.9 \%$ & & & \\
\hline & & \multirow{2}{*}{ Staff } & Freq. & 20 & 25 & 5 & & & \\
\hline & & & $\%$ & $40.0 \%$ & $50.0 \%$ & $10.0 \%$ & & & \\
\hline \multirow{4}{*}{9} & \multirow{4}{*}{$\begin{array}{c}\text { The College organizes } \\
\text { a sports day on a } \\
\text { regular basis }\end{array}$} & \multirow{2}{*}{ Students } & Freq. & 455 & 66 & 9 & \multirow{4}{*}{1.2103} & \multirow{4}{*}{ Weak } & \multirow{4}{*}{6} \\
\hline & & & $\%$ & $85.8 \%$ & $12.5 \%$ & $1.7 \%$ & & & \\
\hline & & \multirow{2}{*}{ Staff } & Freq. & 21 & 20 & 9 & & & \\
\hline & & & $\%$ & $42.0 \%$ & $40.0 \%$ & $18.0 \%$ & & & \\
\hline
\end{tabular}

Table (2) indicated sample responses according to relative weight and incidence degree as following order:

1- The College is keen to form sports teams in different games with a relative weight (2.9862) and large incidence degree.

2- College students participate in sports teams at the university with a relative weight (2.9741) and large incidence degree.

The researcher believes that these results correspond to university students' nature, as they tend to practice sports activities. So, the University is interested in formation of sports teams in colleges, a staff member usually appointed as activities supervisor (cultural, social and sports).

Each college is keen to participate university director's football league every year where the students are highly interested in it, this corresponds to students high attitudes towards football practice.

The researcher noted through interviews with activities supervisors that most of them are not specialized in student activities field. Student activity represents an additional burden on their academic timetable. Therefore, the researcher suggests:

- The university should employ specialists in students' activities field in general and sports activities in particular.

- The researcher urges the university to build an integrated facilities sports stadium within the campus supervised by a group of specialists in different games.

The rest of the phrases in second aspect (sports services) came with weak incidence

The researcher believes that weakness of these services is because that Hail University is an emerging university, and is still completing sports facilities at the university and colleges..

This is in consistent with (Amin \& Abdullah, 2009) study results, which pointed the weakness of health services provided to athletes.

Table (3)

Third aspect responses (Health Nutrition Services) $(n=580)$

\begin{tabular}{|c|c|c|c|c|c|c|c|c|c|}
\hline \multirow[b]{2}{*}{ S.No. } & \multirow[b]{2}{*}{ Phrase } & \multirow[b]{2}{*}{ Group } & \multicolumn{4}{|c|}{ Responses } & \multirow{2}{*}{$\begin{array}{c}\text { Relative } \\
\text { weight }\end{array}$} & \multirow{2}{*}{$\begin{array}{l}\text { Incidenc } \\
\text { e degree }\end{array}$} & \multirow[b]{2}{*}{ Rank } \\
\hline & & & & No & $\begin{array}{c}\text { To some } \\
\text { extent }\end{array}$ & Yes & & & \\
\hline \multirow{3}{*}{1} & \multirow{3}{*}{$\begin{array}{l}\text { Provides meals for } \\
\text { students inside the } \\
\text { college (free - }\end{array}$} & \multirow{2}{*}{ Students } & Freq. & 513 & 9 & 8 & \multirow{3}{*}{1.0914} & \multirow{3}{*}{ Weak } & \multirow{3}{*}{5} \\
\hline & & & $\%$ & $96.8 \%$ & $1.7 \%$ & $1.5 \%$ & & & \\
\hline & & Staff & Freq. & 31 & 10 & 9 & & & \\
\hline
\end{tabular}




\begin{tabular}{|c|c|c|c|c|c|c|c|c|c|}
\hline & partially subsidized) & & $\%$ & $62.0 \%$ & $20.0 \%$ & $18.0 \%$ & & & \\
\hline \multirow{4}{*}{2} & \multirow{4}{*}{$\begin{array}{l}\text { There are enough } \\
\text { restaurants to satisfy } \\
\text { students' needs }\end{array}$} & \multirow{2}{*}{ Students } & Freq. & 513 & 9 & 8 & \multirow{4}{*}{1.0759} & \multirow{4}{*}{ Weak } & \multirow{4}{*}{7} \\
\hline & & & $\%$ & $96.8 \%$ & $1.7 \%$ & $1.5 \%$ & & & \\
\hline & & \multirow{2}{*}{ Staff } & Freq. & 39 & 3 & 8 & & & \\
\hline & & & $\%$ & $78.0 \%$ & $6.0 \%$ & $16.0 \%$ & & & \\
\hline \multirow{4}{*}{3} & \multirow{4}{*}{$\begin{array}{l}\text { Restaurants are } \\
\text { subject to health } \\
\text { supervision }\end{array}$} & \multirow{2}{*}{ Students } & Freq. & 513 & 11 & 6 & \multirow{4}{*}{1.0776} & \multirow{4}{*}{ Weak } & \multirow{4}{*}{6} \\
\hline & & & $\%$ & $96.8 \%$ & $2.1 \%$ & $1.1 \%$ & & & \\
\hline & & \multirow{2}{*}{ Staff } & Freq. & 34 & 10 & 6 & & & \\
\hline & & & $\%$ & $68.0 \%$ & $20.0 \%$ & $12.0 \%$ & & & \\
\hline \multirow{4}{*}{4} & \multirow{4}{*}{$\begin{array}{l}\text { Foods properly } \\
\text { packaged to avoid } \\
\text { microbes }\end{array}$} & \multirow{2}{*}{ Students } & Freq. & 1 & 2 & 527 & \multirow{4}{*}{2.9879} & \multirow{4}{*}{ Large } & \multirow{4}{*}{1} \\
\hline & & & $\%$ & $0.2 \%$ & $0.4 \%$ & $99.4 \%$ & & & \\
\hline & & \multirow{2}{*}{ Staff } & Freq. & 1 & 1 & 48 & & & \\
\hline & & & $\%$ & $2.0 \%$ & $2.0 \%$ & $96.0 \%$ & & & \\
\hline \multirow{4}{*}{5} & \multirow{4}{*}{$\begin{array}{l}\text { Health safety factors } \\
\text { taken into account } \\
\text { in restaurant } \\
\text { equipping }\end{array}$} & \multirow{2}{*}{ Students } & Freq. & 3 & 4 & 523 & \multirow{4}{*}{2.9672} & \multirow{4}{*}{ Large } & \multirow{4}{*}{2} \\
\hline & & & $\%$ & $0.6 \%$ & $0.8 \%$ & $98.7 \%$ & & & \\
\hline & & \multirow{2}{*}{ Staff } & Freq. & 3 & 3 & 44 & & & \\
\hline & & & $\%$ & $6.0 \%$ & $6.0 \%$ & $88.0 \%$ & & & \\
\hline & Health cards are & Students & Freq. & 513 & 11 & 6 & & & \\
\hline 6 & available for & (2) & $\%$ & $96.8 \%$ & $2.07 \%$ & $1.13 \%$ & 10724 & Weak & 8 \\
\hline & restaurant & Staff & Freq. & 39 & 3 & 8 & 1.0721 & mene 5 & \\
\hline & & Stant & $\%$ & $78.0 \%$ & $6.0 \%$ & $16.0 \%$ & & & \\
\hline & & Students & Freq. & 530 & 0 & 0 & & & \\
\hline 7 & Special nutritional & Sturents & $\%$ & $100.0 \%$ & $0.0 \%$ & $0.0 \%$ & 1 & Weok & 0 \\
\hline & athletes & Staff & Freq. & 50 & 0 & 0 & & ment & S \\
\hline & & Stant & $\%$ & $100.0 \%$ & $0.0 \%$ & $0.0 \%$ & & & \\
\hline & & Students & Freq. & 7 & 517 & 6 & & & \\
\hline 8 & Restaurants are keen & & $\%$ & $1.3 \%$ & $97.5 \%$ & $1.1 \%$ & 1.996 & Medium & 3 \\
\hline & healthy meal & Staff & Freq. & 7 & 37 & 6 & & Nortum & 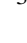 \\
\hline & & & $\%$ & $14.0 \%$ & $74.0 \%$ & $12.0 \%$ & & & \\
\hline & & Students & Freq. & 7 & 515 & 8 & & & \\
\hline 0 & Academic timetable & & $\%$ & $1.3 \%$ & $97.2 \%$ & $1.5 \%$ & $106 ?$ & Medium & \\
\hline & to take meals & Staff & Freq. & 7 & 35 & 8 & 10.02 & 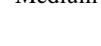 & 7 \\
\hline & & & $\%$ & $14.0 \%$ & $70.0 \%$ & $16.0 \%$ & & & \\
\hline
\end{tabular}

Table (3) indicated sample responses according to relative weight and incidence degree as following order:

1- Foods properly packaged to avoid microbes with a relative weight (2.99) and large incidence degree

2- Health safety factors taken into account in restaurant equipping with a relative weight (2.97) and large incidence degree

These results indicates that university's restaurants, at the time of this research, are only temporary restaurants that are contracted between them and university through Deanship of Student Affairs, and are often dependent on packaged meals and subject to weak supervision by university administration.

The rest of the phrases in third aspect (health nutrition services) came with weak incidence

The researcher believes that these weaknesses indicates the need for the university to pay more attention to these aspects related to food services. 
Table (4)

Fourth aspect responses (Psychological Counselling Services) $(\mathbf{n = 5 8 0})$

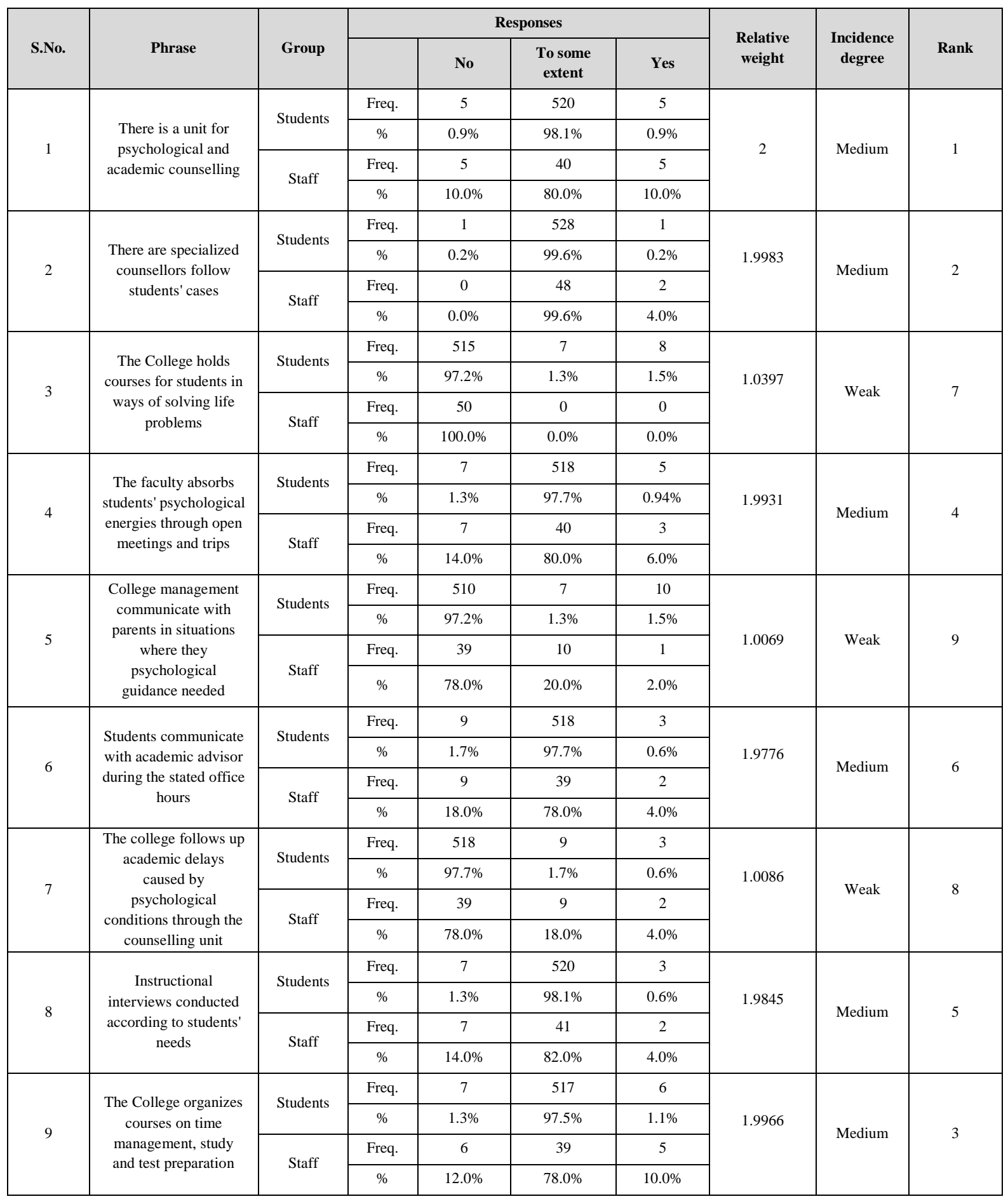

Table (4) indicated sample responses according to 1- There is a unit for psychological and academic relative weight and incidence degree as following order: counselling with a relative weight (2.00) and medium incidence degree 
2- There are specialized counsellors follow students' cases with a relative weight (1.99) and medium incidence degree

These results indicates university interest in psychological counselling aspect, especially in recent years.

This is in line with (Abdullatif, 2011) study results, which indicated that educational programs should include psychological counselling programs, thus reducing number of dropouts from education.
The rest of the phrases in fourth aspect (Psychological Counselling Services) came with weak incidence

The researcher found that colleges organize some public seminars on time management, study and test preparation but do not receive more than $20 \%$ of the students. These seminars aimed at helping students overcome the psychological pressures that accompany exams or the beginning of a new university life.

In researcher opinion, these services are insufficient, and there is a need to activate the office hours for faculty staff members..

Table (5)

Fifth aspect responses (Healthy university environment) $(n=580)$

\begin{tabular}{|c|c|c|c|c|c|c|c|c|c|}
\hline \multirow[b]{2}{*}{ S.No. } & \multirow[b]{2}{*}{ Phrase } & \multirow[b]{2}{*}{ Group } & \multicolumn{4}{|c|}{ Responses } & \multirow{2}{*}{$\begin{array}{c}\text { Relative } \\
\text { weight }\end{array}$} & \multirow{2}{*}{$\begin{array}{c}\text { Incidence } \\
\text { degree }\end{array}$} & \multirow[b]{2}{*}{ Rank } \\
\hline & & & & No & $\begin{array}{c}\text { To some } \\
\text { extent }\end{array}$ & Yes & & & \\
\hline \multirow{4}{*}{1} & \multirow{4}{*}{$\begin{array}{c}\text { The college building } \\
\text { is located away from } \\
\text { pollution and noise }\end{array}$} & \multirow{2}{*}{ Students } & Freq. & 3 & 4 & 523 & \multirow{4}{*}{2.9828} & \multirow{4}{*}{ Large } & \multirow{4}{*}{3} \\
\hline & & & $\%$ & $0.6 \%$ & $0.8 \%$ & $98.7 \%$ & & & \\
\hline & & \multirow{2}{*}{ Staff } & Freq. & 0 & 0 & 50 & & & \\
\hline & & & $\%$ & $0.0 \%$ & $0.0 \%$ & $100.0 \%$ & & & \\
\hline \multirow{4}{*}{2} & \multirow{4}{*}{$\begin{array}{l}\text { Security and safety } \\
\text { factors are available } \\
\text { in the building (fire } \\
\text { extinguishers, } \\
\text { emergency alarms, } \\
\text { etc.) }\end{array}$} & \multirow{2}{*}{ Students } & Freq. & 4 & 519 & 7 & \multirow{4}{*}{2.0052} & \multirow{4}{*}{ Medium } & \multirow{4}{*}{9} \\
\hline & & & $\%$ & $0.8 \%$ & $97.9 \%$ & $1.3 \%$ & & & \\
\hline & & \multirow{2}{*}{ Staff } & Freq. & 4 & 42 & 4 & & & \\
\hline & & & $\%$ & $8.0 \%$ & $84.0 \%$ & $8.0 \%$ & & & \\
\hline \multirow{4}{*}{3} & \multirow{4}{*}{$\begin{array}{c}\text { Classrooms have } \\
\text { good ventilation and } \\
\text { proper lighting }\end{array}$} & \multirow{2}{*}{ Students } & Freq. & 2 & 4 & 524 & \multirow{4}{*}{2.9862} & \multirow{4}{*}{ Large } & \multirow{4}{*}{2} \\
\hline & & & $\%$ & $0.4 \%$ & $0.8 \%$ & $98.9 \%$ & & & \\
\hline & & \multirow{2}{*}{ Staff } & Freq. & 0 & 0 & 50 & & & \\
\hline & & & $\%$ & $0.0 \%$ & $0.0 \%$ & $100.0 \%$ & & & \\
\hline \multirow{4}{*}{4} & & & Freq. & 5 & 3 & 522 & & & \\
\hline & Classroom space & & $\%$ & $0.9 \%$ & $0.6 \%$ & $98.5 \%$ & & & \\
\hline & number of students & & Freq. & 0 & 0 & 50 & של & Watso & \\
\hline & & & $\%$ & $0.0 \%$ & $0.0 \%$ & $100.0 \%$ & & & \\
\hline & The college is located & & Freq. & 3 & 524 & 3 & & & \\
\hline & near the basic & & $\%$ & $0.6 \%$ & $98.9 \%$ & $0.6 \%$ & 2 & Modin & \\
\hline & ambulance - & Staff & Freq. & 0 & 50 & 0 & & 19 & \\
\hline & firefighting - ...) & & $\%$ & $0.0 \%$ & $100.0 \%$ & $0.0 \%$ & & & \\
\hline & & & Freq. & 6 & 520 & 4 & & & \\
\hline & Green spaces and & stuctiots & $\%$ & $1.1 \%$ & $98.1 \%$ & $0.8 \%$ & & & \\
\hline & around the college & Stat & Freq. & 0 & 50 & 0 & 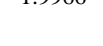 & PVectunt & 11 \\
\hline & & & $\%$ & $0.0 \%$ & $100.0 \%$ & $0.0 \%$ & & & \\
\hline & The administration & & Freq. & 34 & 482 & 14 & & & \\
\hline & $\begin{array}{l}\text { follows up the } \\
\text { cleanliness of roads }\end{array}$ & & $\%$ & $6.4 \%$ & $90.9 \%$ & $2.6 \%$ & & & \\
\hline t & and toilets through a & & Freq. & 0 & 50 & 0 & 1.9655 & Medium & 12 \\
\hline & in hygiene & Stant & $\%$ & $0.0 \%$ & $100.0 \%$ & $0.0 \%$ & & & \\
\hline
\end{tabular}




\begin{tabular}{|c|c|c|c|c|c|c|c|c|c|}
\hline \multirow{4}{*}{8} & \multirow{4}{*}{$\begin{array}{l}\text { College buildings } \\
\text { affected by different } \\
\text { weather conditions }\end{array}$} & \multirow{2}{*}{ Students } & Freq. & 519 & 2 & 9 & \multirow{4}{*}{1.0345} & \multirow{4}{*}{ Weak } & \multirow{4}{*}{13} \\
\hline & & & $\%$ & $97.9 \%$ & $0.4 \%$ & $1.7 \%$ & & & \\
\hline & & \multirow{2}{*}{ Staff } & Freq. & 50 & 0 & 0 & & & \\
\hline & & & $\%$ & $100.0 \%$ & $0.0 \%$ & $0.0 \%$ & & & \\
\hline \multirow{4}{*}{9} & \multirow{4}{*}{$\begin{array}{l}\text { There are trash } \\
\text { baskets well } \\
\text { distributed in } \\
\text { corridors of the } \\
\text { building }\end{array}$} & \multirow{2}{*}{ Students } & Freq. & - & - & 530 & \multirow{4}{*}{3} & \multirow{4}{*}{ Large } & \multirow{4}{*}{1} \\
\hline & & & $\%$ & - & - & $100.0 \%$ & & & \\
\hline & & \multirow{2}{*}{ Staff } & Freq. & - & - & 50 & & & \\
\hline & & & $\%$ & - & - & $100.0 \%$ & & & \\
\hline \multirow{4}{*}{10} & \multirow{4}{*}{$\begin{array}{l}\text { Electrical connections } \\
\text { securely insulated }\end{array}$} & \multirow{2}{*}{ Students } & Freq. & 13 & 10 & 507 & \multirow{4}{*}{2.9017} & \multirow{4}{*}{ Large } & \multirow{4}{*}{8} \\
\hline & & & $\%$ & $2.5 \%$ & $1.9 \%$ & $95.7 \%$ & & & \\
\hline & & \multirow{2}{*}{ Staff } & Freq. & 8 & 5 & 37 & & & \\
\hline & & & $\%$ & $16.0 \%$ & $10.0 \%$ & $74.0 \%$ & & & \\
\hline \multirow{4}{*}{11} & \multirow{4}{*}{$\begin{array}{l}\text { Study rooms floor are } \\
\text { easy to clean }\end{array}$} & \multirow{2}{*}{ Students } & Freq. & 7 & 9 & 514 & \multirow{4}{*}{2.9345} & \multirow{4}{*}{ Large } & \multirow{4}{*}{7} \\
\hline & & & $\%$ & $1.3 \%$ & $1.7 \%$ & $97.0 \%$ & & & \\
\hline & & \multirow{2}{*}{ Staff } & Freq. & 5 & 5 & 40 & & & \\
\hline & & & $\%$ & $10.0 \%$ & $10.0 \%$ & $80.0 \%$ & & & \\
\hline \multirow{4}{*}{12} & \multirow{4}{*}{$\begin{array}{l}\text { Seats are suitable for } \\
\text { students }\end{array}$} & \multirow{2}{*}{ Students } & Freq. & 4 & 3 & 523 & \multirow{4}{*}{2.9621} & & \\
\hline & & & $\%$ & $0.8 \%$ & $0.6 \%$ & $98.7 \%$ & & I arge & 5 \\
\hline & & Staff & Freq. & 4 & 3 & 43 & & Large & 3 \\
\hline & & Stant & $\%$ & $8.0 \%$ & $6.0 \%$ & $86.0 \%$ & & & \\
\hline & & Students & Freq. & 5 & 4 & 521 & & & \\
\hline 13 & Boards' colours are & Soludits & $\%$ & $0.9 \%$ & $0.8 \%$ & $98.3 \%$ & 29517 & Large & 6 \\
\hline 13 & suitable & Staff & Freq. & 5 & 4 & 41 & 2.9511 & Large & 6 \\
\hline & & Stant & $\%$ & $10.0 \%$ & $8.0 \%$ & $82.0 \%$ & & & \\
\hline
\end{tabular}

Table (5) revealed that sample responses in Healthy university environment aspect indicated (8) phrases with large incidence degree, (4) phrases with medium incidence degree, and (1) phrase with weak incidence degree. The researcher returns these results to:

- University facilities modernity for all faculties (except 5), all buildings are temporary.

- Transfer lot of syllabuses from teaching process to training process, which made the halls designed to accommodate appropriate number of students in order to improve training process and achieve its goals.

- Maintenance and hygiene of the university assigned to specialized companies providing employment from $8: 2$ pm.
- Hail area has a wonderful weather and wide green spaces, and the university is far from residential areas $(25 \mathrm{~km})$, away from pollution and noise.

There is no doubt that university's interest in university environment is one of the most important advantages that helps students to love study environment, having physical and psychological comfort during teaching process

This is consistent with (Ibrahim, 2010) study results, which indicated that most educational institutions are concerned with health requirements of buildings and playgrounds. 
Table (6)

Sixth aspect responses (Medical services) $(n=580)$

\begin{tabular}{|c|c|c|c|c|c|c|c|c|c|}
\hline \multirow[b]{2}{*}{ S.No. } & \multirow[b]{2}{*}{ Phrase } & \multirow[b]{2}{*}{ Group } & \multicolumn{4}{|c|}{ Responses } & \multirow{2}{*}{$\begin{array}{c}\text { Relative } \\
\text { weight }\end{array}$} & \multirow{2}{*}{$\begin{array}{c}\text { Incidence } \\
\text { degree }\end{array}$} & \multirow[b]{2}{*}{ Rank } \\
\hline & & & & No & $\begin{array}{c}\text { To some } \\
\text { extent }\end{array}$ & Yes & & & \\
\hline \multirow{4}{*}{1} & \multirow{4}{*}{$\begin{array}{c}\text { The college has first } \\
\text { aid room }\end{array}$} & \multirow{2}{*}{ Students } & Freq. & 510 & 15 & 5 & \multirow{4}{*}{1.0862} & \multirow{4}{*}{ Weak } & \multirow{4}{*}{3} \\
\hline & & & $\%$ & $96.2 \%$ & $2.8 \%$ & $0.9 \%$ & & & \\
\hline & & \multirow{2}{*}{ Staff } & Freq. & 30 & 15 & 5 & & & \\
\hline & & & $\%$ & $60.0 \%$ & $30.0 \%$ & $10.0 \%$ & & & \\
\hline \multirow{4}{*}{2} & \multirow{4}{*}{$\begin{array}{l}\text { The College has } \\
\text { specialists in first aid }\end{array}$} & \multirow{2}{*}{ Students } & Freq. & 505 & 16 & 9 & \multirow{4}{*}{1.1069} & \multirow{4}{*}{ Weak } & \multirow{4}{*}{2} \\
\hline & & & $\%$ & $95.3 \%$ & $3.0 \%$ & $1.7 \%$ & & & \\
\hline & & \multirow{2}{*}{ Staff } & Freq. & 31 & 10 & 9 & & & \\
\hline & & & $\%$ & $62.0 \%$ & $20.0 \%$ & $18.0 \%$ & & & \\
\hline \multirow{4}{*}{3} & \multirow{4}{*}{$\begin{array}{c}\text { First-aid kits are } \\
\text { available at college }\end{array}$} & & Freq. & 513 & 9 & 8 & & & \\
\hline & & students & $\%$ & $96.8 \%$ & $1.7 \%$ & $1.5 \%$ & & & \\
\hline & & Ctos & Freq. & 41 & 0 & 9 & 1.0141 & weak & 4 \\
\hline & & & $\%$ & $82.0 \%$ & $0.0 \%$ & $18.0 \%$ & & & \\
\hline & & & Freq. & 7 & 509 & 14 & & & \\
\hline 4 & Faculty held first aid & Students & $\%$ & $1.3 \%$ & $96.0 \%$ & $2.6 \%$ & 20121 & Medium & 1 \\
\hline 4 & courses by specialists & Ctoc & Freq. & 0 & 50 & 0 & 2.0121 & iviecuint & 1 \\
\hline & & Stant & $\%$ & $0.0 \%$ & $100.0 \%$ & $0.0 \%$ & & & \\
\hline & & Cot l & Freq. & 520 & 9 & 1 & & & \\
\hline 5 & University has medical & Students & $\%$ & $98.1 \%$ & $1.7 \%$ & $0.2 \%$ & 1010 & W & 10 \\
\hline & students and staff & Stoff & Freq. & 50 & 0 & 0 & 1.019 & weak & 10 \\
\hline & & Stail & $\%$ & $100.0 \%$ & $0.0 \%$ & $0.0 \%$ & & & \\
\hline & & Cot l t & Freq. & 516 & 11 & 3 & & & \\
\hline & The university adopts & students & $\%$ & $97.4 \%$ & $2.1 \%$ & $0.6 \%$ & & & \\
\hline 0 & insurance system & Staff & Freq. & 50 & 0 & 0 & 1.0295 & weak & 0 \\
\hline & & Stall & $\%$ & $100.0 \%$ & $0.0 \%$ & $0.0 \%$ & & & \\
\hline & & $S_{\mathrm{S}}$ & Freq. & 520 & 8 & 2 & & & \\
\hline 7 & $\begin{array}{l}\text { The health services } \\
\text { provided to students }\end{array}$ & Students & $\%$ & $98.1 \%$ & $1.5 \%$ & $0.4 \%$ & 10207 & Weak & 9 \\
\hline$t$ & shown in the university & Stoff & Freq. & 50 & 0 & 0 & & & \\
\hline & & Stall & $\%$ & $100.0 \%$ & $0.0 \%$ & $0.0 \%$ & & & \\
\hline & & Ct t l & Freq. & 518 & 9 & 3 & & & \\
\hline 8 & procedures are & & $\%$ & $97.7 \%$ & $1.7 \%$ & $0.6 \%$ & 10250 & Weak & 7 \\
\hline 0 & available in each & Staff & Freq. & 50 & 0 & 0 & 1.0259 & weak & 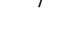 \\
\hline & & Stall & $\%$ & $100.0 \%$ & $0.0 \%$ & $0.0 \%$ & & & \\
\hline & & $S_{1}$ & Freq. & 521 & 3 & 6 & & & \\
\hline 9 & There is an equipped & Students & $\%$ & $98.3 \%$ & $0.6 \%$ & $1.1 \%$ & 10259 & Weak & 8 \\
\hline & & Stoff & Freq. & 50 & 0 & 0 & & & \\
\hline & & Stall & $\%$ & $100.0 \%$ & $0.0 \%$ & $0.0 \%$ & & & \\
\hline & & $\mathrm{S}_{\mathrm{S}} \longrightarrow$ & Freq. & 496 & 31 & 3 & & & \\
\hline 10 & clinic inside the & Students & $\%$ & $93.6 \%$ & $5.8 \%$ & $0.6 \%$ & 10628 & Wol. & 5 \\
\hline 10 & college with & Staff & Freq. & 50 & 0 & 0 & 1.0638 & Weak & 5 \\
\hline & & Stant & $\%$ & $100.0 \%$ & $0.0 \%$ & $0.0 \%$ & & & \\
\hline
\end{tabular}


Table (6) revealed that sample responses in Healthy university environment aspect indicated (9) phrases with weak incidence degree, and (1) phrase with medium incidence degree (Faculty held first aid courses by specialists). The researcher returns these results to:

- Colleges are only holding theoretical seminars in first aid in cooperation with Saudi Red Crescent Society, and this is not enough for practical training.

- University depend only on government clinics, which wastes student time.

The researcher hopes that the university will seek to provide appropriate medical services for students. There is need to facilitate medical referral procedures and provide a doctor and first aid specialist in each college. Medical referral procedures to be published in student's guide and on university website.

This is what (Al-Aklabi \& Al-Refaei, 2012) study recommended, which pointed out that implementation of TQM principles in health field leads to improve health services level.

Researcher believes that medical care availability with easy procedures creates suitable climate and helps to enjoy good health and educational attainment.

Table (7)

Seventh aspect responses (staff members) (Health services quality) $(n=50)$

\begin{tabular}{|c|c|c|c|c|c|c|c|c|}
\hline S.No & Phrases & & No & $\begin{array}{c}\text { To some } \\
\text { extent }\end{array}$ & Yes & $\begin{array}{c}\text { Relative } \\
\text { weight }\end{array}$ & $\begin{array}{l}\text { Quality } \\
\text { degree }\end{array}$ & Rank \\
\hline \multirow[b]{2}{*}{1} & \multirow{2}{*}{$\begin{array}{l}\text { College administration is } \\
\text { concerned with students when } \\
\text { they submit complaints } \\
\text { concerning health aspects }\end{array}$} & Freq. & 17 & 32 & 1 & \multirow[b]{2}{*}{1.0586} & \multirow[b]{2}{*}{ Weak } & \multirow[b]{2}{*}{3} \\
\hline & & $\%$ & $34.0 \%$ & $64.0 \%$ & $2.0 \%$ & & & \\
\hline \multirow[b]{2}{*}{2} & \multirow{2}{*}{$\begin{array}{l}\text { Waiting places in clinics, } \\
\text { doctors' offices and staff are } \\
\text { in line with health quality } \\
\text { standards }\end{array}$} & Freq. & 46 & 3 & 1 & \multirow[b]{2}{*}{1.0086} & \multirow[b]{2}{*}{ Weak } & \multirow[b]{2}{*}{19} \\
\hline & & $\%$ & $92.0 \%$ & $6.0 \%$ & $2.0 \%$ & & & \\
\hline \multirow{2}{*}{3} & \multirow{2}{*}{$\begin{array}{l}\text { The University administration } \\
\text { provides full support to } \\
\text { students in health aspects }\end{array}$} & Freq. & 26 & 21 & 3 & \multirow{2}{*}{1.0466} & \multirow{2}{*}{ Weak } & \multirow{2}{*}{6} \\
\hline & & $\%$ & $52.0 \%$ & $42.0 \%$ & $6.0 \%$ & & & \\
\hline \multirow{2}{*}{4} & \multirow{2}{*}{$\begin{array}{c}\text { University administration } \\
\text { provides full support to health } \\
\text { workers }\end{array}$} & Freq. & 17 & 30 & 3 & \multirow{2}{*}{1.0621} & \multirow{2}{*}{ Weak } & \multirow{2}{*}{2} \\
\hline & & $\%$ & $34.0 \%$ & $60.0 \%$ & $6.0 \%$ & & & \\
\hline \multirow{2}{*}{5} & \multirow{2}{*}{$\begin{array}{l}\text { University administration } \\
\text { provides physical resources to } \\
\text { provide medical supplies }\end{array}$} & Freq. & 45 & 4 & 1 & \multirow{2}{*}{1.0103} & \multirow{2}{*}{ Weak } & \multirow{2}{*}{18} \\
\hline & & $\%$ & $90.0 \%$ & $8.0 \%$ & $2.0 \%$ & & & \\
\hline \multirow{2}{*}{6} & \multirow{2}{*}{$\begin{array}{l}\text { Health care for students is } \\
\text { highly satisfactory }\end{array}$} & Freq. & 47 & 3 & & \multirow{2}{*}{1.0052} & \multirow{2}{*}{ Weak } & \multirow{2}{*}{23} \\
\hline & & $\%$ & $94.0 \%$ & $6.0 \%$ & & & & \\
\hline \multirow{2}{*}{7} & \multirow{2}{*}{$\begin{array}{l}\text { Quality standards followed to } \\
\text { help determine results of } \\
\text { service offered to students }\end{array}$} & Freq. & 46 & 3 & 1 & & & \\
\hline & & $\%$ & $92.0 \%$ & $6.0 \%$ & $2.0 \%$ & 1.0086 & Weak & 20 \\
\hline & Students (and community) & Freq. & 14 & 35 & 1 & & & \\
\hline 8 & $\begin{array}{l}\text { acceptance considered when } \\
\text { using any health procedure }\end{array}$ & $\%$ & $28.0 \%$ & $70.0 \%$ & $2.0 \%$ & 1.0638 & Weak & 1 \\
\hline & There are no waiting lists for & Freq. & 43 & 5 & 2 & & & \\
\hline 9 & $\begin{array}{l}\text { appontments at the on-site } \\
\text { clinic or outpatient clinics }\end{array}$ & $\%$ & $86.0 \%$ & $10.0 \%$ & $4.0 \%$ & 1.0155 & Weak & 13 \\
\hline & The resources and costs & Freq. & 45 & 5 & & & & \\
\hline 10 & $\begin{array}{l}\text { optimized to deliver premium } \\
\text { health services }\end{array}$ & $\%$ & $90.0 \%$ & $10.0 \%$ & & 1.0086 & Weak & 21 \\
\hline & The patient's information kept & Freq. & 45 & 3 & 2 & & & \\
\hline 11 & $\begin{array}{l}\text { in records to follow up health } \\
\text { state }\end{array}$ & $\%$ & $90.0 \%$ & $6.0 \%$ & $4.0 \%$ & 1.0121 & Weak & 17 \\
\hline & Public morals considered & Freq. & 23 & 23 & 4 & & & \\
\hline 12 & $\begin{array}{c}\text { when providing student health } \\
\text { services }\end{array}$ & $\%$ & $46.0 \%$ & $46.0 \%$ & $8.0 \%$ & 1.0534 & Weak & 5 \\
\hline
\end{tabular}




\begin{tabular}{|c|c|c|c|c|c|c|c|c|}
\hline \multirow{2}{*}{13} & The student's opinion on & Freq. & 41 & 4 & 5 & \multirow{2}{*}{1.0241} & \multirow{2}{*}{ Weak } & \multirow{2}{*}{10} \\
\hline & him taken into account & $\%$ & $82.0 \%$ & $8.0 \%$ & $10.0 \%$ & & & \\
\hline \multirow{2}{*}{14} & Clear standards and & Freq. & 30 & 18 & 2 & \multirow{2}{*}{1.0379} & \multirow{2}{*}{ Weak } & \multirow{2}{*}{8} \\
\hline & dealing with students & $\%$ & $60.0 \%$ & $36.0 \%$ & $4.0 \%$ & & & \\
\hline \multirow[b]{2}{*}{15} & \multirow{2}{*}{$\begin{array}{l}\text { The students notified of times } \\
\text { and procedures of health } \\
\text { services provision in hospitals } \\
\text { of the University }\end{array}$} & Freq. & 42 & 7 & 1 & \multirow[b]{2}{*}{1.0155} & \multirow[b]{2}{*}{ Weak } & \multirow[b]{2}{*}{14} \\
\hline & & $\%$ & $84.0 \%$ & $14.0 \%$ & $2.0 \%$ & & & \\
\hline \multirow[b]{2}{*}{16} & \multirow{2}{*}{$\begin{array}{l}\text { The university administration } \\
\text { is interested in providing } \\
\text { students' health services in a } \\
\text { confidential and accurate } \\
\text { manner }\end{array}$} & Freq. & 43 & 5 & 2 & \multirow[b]{2}{*}{1.0145} & \multirow[b]{2}{*}{ Weak } & \multirow[b]{2}{*}{15} \\
\hline & & $\%$ & $86.0 \%$ & $10.0 \%$ & $4.0 \%$ & & & \\
\hline \multirow[b]{2}{*}{17} & \multirow{2}{*}{$\begin{array}{l}\text { Health services provided for } \\
\text { all students (patients, } \\
\text { handicapped, chronic } \\
\text { diseases) }\end{array}$} & Freq. & 17 & 33 & & \multirow[b]{2}{*}{1.0569} & \multirow[b]{2}{*}{ Weak } & \multirow[b]{2}{*}{4} \\
\hline & & $\%$ & $34.0 \%$ & $66.0 \%$ & & & & \\
\hline \multirow[b]{2}{*}{18} & \multirow{2}{*}{$\begin{array}{l}\text { Quality Management sets } \\
\text { specific standards for healthy } \\
\text { nutrition services offered to } \\
\text { students }\end{array}$} & Freq. & 43 & 5 & 2 & \multirow[b]{2}{*}{1.0155} & \multirow[b]{2}{*}{ Weak } & \multirow[b]{2}{*}{16} \\
\hline & & $\%$ & $86.0 \%$ & $10.0 \%$ & $4.0 \%$ & & & \\
\hline \multirow{2}{*}{19} & \multirow{2}{*}{$\begin{array}{l}\text { Quality Management sets } \\
\text { specific standards for sports } \\
\text { services offered to students }\end{array}$} & Freq. & 40 & 10 & & \multirow{2}{*}{1.0172} & \multirow{2}{*}{ Weak } & \multirow{2}{*}{12} \\
\hline & & $\%$ & $80.0 \%$ & $20.0 \%$ & & & & \\
\hline \multirow[b]{2}{*}{20} & Quality Management sets & Freq. & 40 & 4 & 6 & & & \\
\hline & $\begin{array}{l}\text { specific standards for } \\
\text { psychological counselling } \\
\text { services offered to students }\end{array}$ & $\%$ & $80.0 \%$ & $8.0 \%$ & $12.0 \%$ & 1.0276 & Weak & 9 \\
\hline & Quality management sets & Freq. & 45 & 5 & & & & \\
\hline 21 & $\begin{array}{l}\text { healthy university } \\
\text { environment }\end{array}$ & $\%$ & $90.0 \%$ & $10.0 \%$ & & 1.0086 & Weak & 22 \\
\hline & Quality Management sets & Freq. & 41 & 7 & 2 & & & \\
\hline 22 & services provided to students & $\%$ & $82.0 \%$ & $14.0 \%$ & $4.0 \%$ & 1.019 & weak & 11 \\
\hline & University health services are & Freq. & 44 & 5 & 1 & & & \\
\hline 25 & $\begin{array}{l}\text { standards } \\
\text { s. }\end{array}$ & $\%$ & $88.0 \%$ & $10.0 \%$ & $2.0 \%$ & 1.0440 & weak & t \\
\hline
\end{tabular}

Table (7) revealed that staff members sample responses in Health services quality aspect indicated that all phrases had weak incidence degree (between 1.0001.06). The researcher returns these results to:

- University focus on some quality aspects only, including curricula development and description, and ignoring health services quality.

- Quality is concerned only with paper files and school buildings, and do not take into account these health services, as there are no forms to measure these health aspects.

This is what (Al-Aklabi \& Al-Refaei, 2012) confirmed that application of total quality principles in health field is of the most important conditions of accreditation in accordance with the TQM principles.
The researcher believes that health services are of most important services that countries have to provide, whether preventive or curative services.

Health services are a fundamental right of every member of society, because human health is the true measure of happiness and well-being. (Qassem, 2005)

\section{Conclusions}

1- Effectiveness of questionnaire prepared in measuring health services quality in Hail University.

2- Lack of quality standards in health services provided to university students 


\section{Recommendations}

1- Preparing health education syllabus to be taught to students at the university.

2- Holding periodic seminars for university students in health issues.

3- Coordinating with the Saudi Red Crescent to provide courses for students in first aid.

4- Provision of a specialist in first aid at colleges.

5- Establishment of restaurants at university offers meals that meet health requirements.

6- Holding seminars in colleges for students on various life problems solving methods.

7- Preparing health awareness programs on university website.

8- Provision of qualified psychologists and health supervisors in universities.

\section{References}

1- Abdulazim, S., \& Abdulrazeq, M. (2002). Teacher accreditation standards in Egypt in light of some recent global trends. Arabic education future, 8(24). (In Arabic)

2- Abdulfatah, S. F., \& Abu Dalbouh, M. (2014). Health and fitness. Riyadh, Saudi Arabia: Qelaa Al-elm. (In Arabic)

3- Abdullatif, F. (2011). Towards an integrated mental health strategy. Childhood and Health, (2). (In Arabic)

4- Al-Ahamadi, H. A. (2000). Continuous improvement of quality: concepts and application in health organizations. Public Administration Journal, Research center, 40(3), 409-443. (In Arabic)

5- Al-Aklabi, A. S., \& Al-Refaei, M. S. (2012). Effect of applying health services quality accreditation, field study on a number of Jordanian and Saudi hospitals. Reading and knowledge, Egypt, (130), 240256. (In Arabic)

6- Al-Emary, H. A. (2011). Compliance with international quality standards in health services sector in Saudi Arabia: An exploratory study in Jeddah. Arab Journal of Administration, Arab Administrative Development Organization, 31(2), 37-80. (In Arabic)

7- Alhayati B. B. (2008). Assessment of health services efficiency in Haditha city. Al-Anbar University Journal for Humanities, (14), 290-296. (In Arabic)

8- Al-Shamaa, N. K. (2014). Total Quality Management as an introduction to development of sports activities management at Umm Al-Qura University (Unpublished master's thesis). Faculty of education, Umm Al-Qura University, Mekka, Saudi Arabia. (In Arabic)

9- Amin, A. I. (2015). Health services in classroom and extracurricular activities in some Azhar secondary institutes according to educational quality and accreditation standards (Unpublished master's thesis). Faculty of physical education, Mansoura University, Mansoura, Egypt. (In Arabic)

10- Amin, M. M., \& Abdullah, M. S. (2009). University students' awareness of certain areas of health education: field study. New valley scientific journal, Asuit university, 1(22). (In Arabic)

11- Ibrahim, H. A. (2010). Evaluating health services for secondary schools students in Qalioubia governorate (Unpublished master's thesis). Faculty of physical education, Tanta University, Tanta, Egypt. (In Arabic)

12- Ismail, A. M. (2006). The effectiveness of a proposed sports program on spreading health culture within basic education first phase students in Minya (Unpublished master's thesis). Faculty of physical education, Minya University, Minya, Egypt. (In Arabic)

13- National authority for quality assurance and accreditation of education. (2009). student guide to accreditation. Cairo, Egypt: Author. (In Arabic)

14- Qassem, M. (2005). Healthy life. Cairo, Egypt: Alm Alkotb. (In Arabic)

15- Qassem, T. M. (2008). TQM and its impact on health institutions (Unpublished master's thesis). Omdurman University, Omdurman, Sudan. (In Arabic)

16- Ramadan, I. M. (2012). Suggested standards for evaluating physical education teacher performance according to quality and accreditation requirements in education. In The Second International Arab Conference on Quality (IACQA). Bahrain, Bahrain: Arab scientific community organization. (In Arabic)

17- Steppa, H (1994). The status of comprehensive school health education and program criteria in Michigan public school. Dissertation.

18- Swedan, W. A. (1999). A comparative study of health services among some disabled and the healthy national teams (Unpublished master's thesis). Faculty of physical education, Helwan University, Giza, Egypt. (In Arabic) 